\title{
Biological response of an in vitro human 3D lung cell model exposed to brake wear debris varies based on brake pad formulation
}

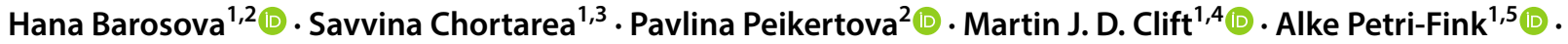 \\ Jana Kukutschova ${ }^{2} \cdot$ Barbara Rothen-Rutishauser $^{1}$ (i)
}

Received: 17 March 2018 / Accepted: 3 May 2018 / Published online: 10 May 2018

(c) The Author(s) 2018

\begin{abstract}
Wear particles from automotive friction brake pads of various sizes, morphology, and chemical composition are significant contributors towards particulate matter. Knowledge concerning the potential adverse effects following inhalation exposure to brake wear debris is limited. Our aim was, therefore, to generate brake wear particles released from commercial low-metallic and non-asbestos organic automotive brake pads used in mid-size passenger cars by a full-scale brake dynamometer with an environmental chamber simulating urban driving and to deduce their potential hazard in vitro. The collected fractions were analysed using scanning electron microscopy via energy-dispersive X-ray spectroscopy (SEM-EDS) and Raman microspectroscopy. The biological impact of the samples was investigated using a human 3D multicellular model consisting of human epithelial cells (A549) and human primary immune cells (macrophages and dendritic cells) mimicking the human epithelial tissue barrier. The viability, morphology, oxidative stress, and (pro-)inflammatory response of the cells were assessed following $24 \mathrm{~h}$ exposure to $\sim 12, \sim 24$, and $\sim 48 \mu \mathrm{g} / \mathrm{cm}^{2}$ of non-airborne samples and to $\sim 3.7 \mu \mathrm{g} / \mathrm{cm}^{2}$ of different brake wear size fractions $(2-4,1-2$, and $0.25-1 \mu \mathrm{m})$ applying a pseudo-air-liquid interface approach. Brake wear debris with low-metallic formula does not induce any adverse biological effects to the in vitro lung multicellular model. Brake wear particles from non-asbestos organic formulated pads, however, induced increased (pro-)inflammatory mediator release from the same in vitro system. The latter finding can be attributed to the different particle compositions, specifically the presence of anatase.
\end{abstract}

Keywords Brake wear particles $\cdot$ Toxicity $\cdot 3 \mathrm{D}$ model of the human alveolar epithelial tissue barrier $\cdot$ In vitro $\cdot$ Full-scale automotive brake dynamometer

Electronic supplementary material The online version of this article (https://doi.org/10.1007/s00204-018-2218-8) contains supplementary material, which is available to authorized users.

Barbara Rothen-Rutishauser

barbara.rothen@unifr.ch

Hana Barosova

hana.barosova@unifr.ch

Savvina Chortarea

savvina.chortarea@empa.ch

Pavlina Peikertova

pavlina.peikertova@vsb.cz

Martin J. D. Clift

m.j.d.clift@swansea.ac.uk

Alke Petri-Fink

alke.fink@unifr.ch

Jana Kukutschova

jana.kukutschova@vsb.cz
1 BioNanomaterials Group, Adolphe Merkle Institute, University of Fribourg, Chemin des Verdiers 4, 1700 Fribourg, Switzerland

2 Nanotechnology Centre, VŠB-Technical University of Ostrava, Ostrava, Czech Republic

3 Laboratory for Materials-Biology Interactions, Empa, Swiss Federal Laboratories for Materials, Science and Technology, St. Gallen, Switzerland

4 In Vitro Toxicology Group, Swansea University Medical School, Swansea, Wales, UK

5 Chemistry Department, University of Fribourg, Fribourg, Switzerland 


\section{Introduction}

Traffic-related air pollutants can be released into the environment by exhaust and non-exhaust emissions (Grigoratos and Martini 2015). Exhaust emissions derive mainly from combustion processes by, e.g., diesel or gasoline cars, whereas non-exhaust particles can be generated from wear of brakes, tyres, clutches, and road surfaces (Thorpe and Harrison 2008). Due to stricter controls of exhaust emissions, the relative contribution of non-exhaust sources to traffic-related emissions is increasing. Recent studies have shown that brake wear particles can contribute up to $55 \%$ of the total non-exhaust traffic-related $\mathrm{PM}_{10}$ (particulate matter $\leq 10 \mu \mathrm{m}$ ) emissions and up to $21 \%$ of total traffic-related $\mathrm{PM}_{10}$ emissions in urban areas (Harrison et al. 2012; Lawrence et al. 2013).

Braking systems are one of the critical elements for traffic safety. The formulation of friction composites is important for the proper function of the complete system. Automotive friction composites are multicomponent formulas consisting of more than ten components; however, producers can use up to 2000 different components for specific composites (Filip et al. 1997). The formulation and amount of each component are considered proprietary by manufacturers and thus make the characterisation of commercially available brake pad materials challenging. However, regular automotive brake pads contain five basic types of components in general, i.e., fibers (e.g., various metals, carbon, glass, and Kevlar) which provide mechanical strength, abrasives (e.g., aluminium and iron oxides, quartz (silicon oxide), and zirconium oxide) to increase friction, lubricants (e.g., graphite and various metal sulphides) to stabilize the friction properties at high temperature, fillers (e.g., barite, calcite, and mica) to improve manufacturability, and binders (e.g., phenolic resin) to maintain the structural integrity under mechanical and thermal stress (Thorpe and Harrison 2008). Kukutschova et al. (2011) studied airborne wear particles released from low-metallic commercial friction composites and detected the emission of nano-sized particles with a diameter around $20 \mathrm{~nm}$ at concentrations about several millions per cubic centimeter. Emitted airborne wear particles were separated into several nano- and micro-sized fractions and $20 \mathrm{~nm}$ particles were detected to be attached to the surface of larger particles. Furthermore, high temperatures and pressures during braking can evoke the transformation of some raw materials [Antimony trisulfide $\left(\mathrm{Sb}_{2} \mathrm{~S}_{3}\right)$ ] into new compounds [Antimony pentoxide $\left(\mathrm{Sb}_{2} \mathrm{O}_{5}\right)$, Laves $\mathrm{Sb}_{2} \mathrm{Fe}$ phase], which may also pose a potential risk to human health (Uexküll et al. 2005). Garg et al. (2000) estimated the total brake wear for a small car in range of $3.2-8.8 \mathrm{mg} /$ $\mathrm{km}$ according to the type of tested pad among wear debris generated from "non-asbestos formulations". Particle sizes range from 0.5 to $10 \mu \mathrm{m}$, and the average size is around $6 \mu \mathrm{m}$. Furthermore, 35\% of brake pad mass loss was emitted as airborne particles with $86 \%$ of the airborne particles smaller than $10 \mu \mathrm{m}\left(\mathrm{PM}_{10}\right)$ and $63 \%$ smaller than $2.5 \mu \mathrm{m}$ in diameter $\left(\mathrm{PM}_{2.5}\right)$ (Sanders et al. 2003). Hagino et al. (2016) observed brake wear particle emission from nonasbestos organic brake pads in a range of $0.04-1.4 \mathrm{mg} / \mathrm{km} /$ vehicle for $\mathrm{PM}_{10}$ and $0.04-1.2 \mathrm{mg} / \mathrm{km} /$ vehicle for $\mathrm{PM}_{2.5}$. Brake wear particles were produced by a brake wear dynamometer with a constant volume sampling system using both passenger cars and middle-class trucks. The proportion of brake wear particles emitted as airborne was $2-21 \%$ of the total mass of overall wear debris (Hagino et al. 2016).

Traffic intensity is one of the most important determinants of ambient, anthropogenic PM concentration, and people living in cities and near major traffic routes are particularly affected by high levels of PM pollution (Wiedensohler et al. 2000). Ambient PM was found to cause adverse health effects associated with increased pulmonary and cardiovascular mortality (Peters et al. 1997; Schulz et al. 2005; Sun et al. 2010). Studies have demonstrated that particle size affects particle deposition in the respiratory tract (Kumar et al. 2013; Pope et al. 2002; Samet et al. 2000). Coarse particles in the size range of several $\mu \mathrm{m}$ are mainly deposited in the upper respiratory tract, while ultrafine particles $(<100 \mathrm{~nm})$ can penetrate into the deep lung (Stone et al. 2017). Particles that are inhaled and deposited on the alveolar lung cell surface can induce oxidative stress and (pro-) inflammatory reactions leading to more severe lung diseases such as chronic obstructive pulmonary disease (Balakrishna et al. 2009; Karlsson et al. 2005; Oberdörster et al. 2005). In vivo studies have shown that ultrafine particles can translocate across the air-blood barrier into the bloodstream and thus reach secondary organs including the liver, kidneys, and brain (Geiser and Kreyling 2010; Oberdörster et al. 2005; Tjalve and Henriksson 1999). The World Health Organisation reported that adverse health effects (i.e., respiratory, cardiovascular morbidity, and lung cancer) of inhalable PM can occur due to exposure over both short (hours, days) and long (months, years) time frames (World Health Organisation 2013).

A considerable fraction of brake wear particles have diameters < $100 \mathrm{~nm}$ (Garg et al. 2000; Mathissen et al. 2011), thus concerns regarding their potential adverse health effects associated with their inhalation have been raised. Only few studies have focused on potential health risks of brake wear particles. Gasser et al. (2009) exposed lung cells (A549 alveolar epithelial monoculture) directly to freshly emitted wear particles. Their results suggest that brake wear particles derived from a "full stop" braking pattern caused a small increase in the (pro-)inflammatory response (interleukin- 8 
release) in the lung epithelial cells after $24 \mathrm{~h}$ post-exposure. This finding was most likely associated with increased concentrations of organic compounds and carbon black.

The aim of the current study was to assess a possible correlation of brake pads composition with the physicochemical characteristics of the released particles and the impact of these particles upon a human 3D lung model in vitro mimicking the human alveolar epithelial tissue barrier (Rothen-Rutishauser et al. 2005). First, investigation of the physico-chemical properties of brake wear debris particles, dependent on the initial brake pad formulation, was performed. Second, exposure of the particles using a pseudo-air liquid interface (pseudo-ALI) approach, as previously described (Endes et al. 2014), with the lung model consisting of A549 (alveolar epithelial type II cells) with human primary macrophages (MDMs) and dendritic cells (MDDCs) was applied to investigate the potential health risks corresponding to the brake pad formulation as well as size fraction of brake wear particles at realistic lifetime doses.

\section{Materials and methods}

\section{Sample preparation}

Brake wear particles were generated and collected according to a procedure simulating urban driving conditions (speed below $80 \mathrm{~km} / \mathrm{h}$, rotor temperature between 200 and $500{ }^{\circ} \mathrm{C}$ ). Brake dynamometer tests were performed using the fullscale brake dynamometer model M2800 (Link Engineering Co., USA, shown in Supplementary Fig. 1a) with the brake system closed in an environmental chamber. The chamber contains the entire front wheel with a disc and caliper and it also contains a wind tunnel simulating a corresponding airflow. The chamber was cleaned before each test and the non-airborne wear debris were collected by sweeping the surfaces of a plastic bin placed at the bottom of the chamber. Airborne particles were captured and separated by sizeresolved sampling into different size fractions using the aerosol sampling system NANO-ID SELECT (PMS Inc., USA) including 12 channels with the size range $0.001-35 \mu \mathrm{m}$. The investigated size fractions $(2-4,1-2$, and $0.25-1 \mu \mathrm{m})$ were collected on the glass side. The controlled filtered air had a flow capacity of $25 \mathrm{~L} / \mathrm{min}$ during the testing procedure. The brake pads used for the generation of wear particles were sorted based on the initial brake pad formulation. Brake pads with a 'low-metallic' formulation (i.e., below $3 \mathrm{wt} \%$ of metallic components) were used for the generation of non-airborne fraction samples [marked as 'non-airborne low-metallic' sample (nLM)] and for the generation of different size fractions $(2-4,1-2$, and $0.25-1 \mu \mathrm{m})$ of brake wear particles [marked as 'size fractions of low-metallic' sample
( $f \mathrm{LLM})]$. Brake pads with non-asbestos organic (NAO) formulation were used for generation of the non-airborne fraction, size fractions of NAO could not be collected and size-sorted because of high carbonaceous content revealing the equipment limitations.

\section{Sample characterisation}

All samples were analysed using SEM (MIRA 3, TESCAN, Czech Republic) with EDS. The powder samples were applied onto the carbon tape and spin-coated with $4 \mathrm{~nm}$ layer of gold to obtain effective electrical conductivity. The secondary electron (SE) mode was used for observing all samples by either SE or InBeam detector. EDS detector was used to determine the elemental composition.

Phase analysis of all powder samples was performed by Raman microspectroscopy using Smart Raman microscopy (System XploRA ${ }^{\mathrm{TM}}$, HORIBA Jobin Yvon, France). Raman spectra were acquired with a $532 \mathrm{~nm}$ excitation laser source, and 1200 grooves/mm grating.

The brake wear particles' morphology was investigated via transmission Electron microscopy (TEM, Fei Technai Spirit, USA) operating at $120 \mathrm{kV}$ and equipped with a Veleta CCD camera (Olympus, Japan). Particles were suspended in deionized water, sonicated for $90 \mathrm{~min}$ and a drop of $20 \mu \mathrm{L}$ was pipetted on TEM copper grids.

\section{Endotoxin content}

Endotoxin content of each non-airborne sample (i.e., nLM, NAO) was assessed. Samples at concentrations of 2, 1, and $0.5 \mathrm{mg} / \mathrm{mL}$ suspended in endotoxin-free water were analysed. Quantification of the endotoxin content was performed after $1 \mathrm{~h}$ of incubation (at $37{ }^{\circ} \mathrm{C}, 5 \% \mathrm{CO}_{2}$ ) using the Pierce ${ }^{\mathrm{TM}}$ LAL Chromogenic Endotoxin Quantitation Kit (cat. no.: 88282; Thermo Scientific, USA). No endotoxin content was detected (value $<0.5 \mathrm{EU} / \mathrm{mL}$ ) in all samples.

\section{D human alveolar lung model}

The co-culture model consisted of human epithelial type-II cells (A549 cell line), combined with primary human blood monocyte derived macrophages (MDMs) and dendritic cells (MDDCs) as described by Lehmann et al. (2010). Detailed description can be found in Electronic Supplementary material (SI).

Briefly, cells were cultured in Roswell Park Memorial Institute medium 1640 supplemented with $10 \%$ fetal bovine serum, $1 \%$ penicillin/streptomycin, and $1 \%$ L-glutamine (sRPMI, all Gibco, USA) at $37^{\circ} \mathrm{C}, 5 \% \mathrm{CO}_{2}$. Epithelial cells were seeded at a density of $2.4 \times 10^{5} \mathrm{cells} / \mathrm{cm}^{2}$, in BD Falcon cell culture inserts. Inserts were placed in culture plates (BD Biosciences, Switzerland) and cells were grown for 5 days 
under submerged conditions. Peripheral human blood monocytes were isolated from human blood buffy coats (Blood Donation Service, Bern University hospital, Bern, Switzerland), as previously described by Lehmann et al. (2010) using $\mathrm{CD} 14^{+}$MicroBeads (Miltenyi Biotec GmbH, Germany) according to the manufacturer's protocol. Monocytes were cultured for 7 days prior to assembling the co-culture. For the cell differentiation the growth factors [GM-CSF and IL-4 (both [10 ng/mL]) for MDDCs and M-CSF [10 ng/mL] for MDMs] were applied to the medium. The co-culture models were assembled, as previously described (Blank et al. 2007). After $24 \mathrm{~h}$ under submerged conditions the cocultures were transferred to the ALI conditions, by removing the medium in the upper chamber and replacing the medium in the lower chamber with $1.2 \mathrm{~mL}$ of fresh culture medium in 6-well plate or $0.6 \mathrm{~mL}$ in 12-well plate, respectively. The cells were then exposed to air for an additional $24 \mathrm{~h}$ prior the exposures being performed.

\section{Lung cell exposures}

The particles were directly suspended in sRPMI medium and sonicated for $90 \mathrm{~min}$ prior exposure. Co-cultures grown in 6-well plate inserts at the ALI were then exposed to $100 \mu \mathrm{L}$ suspended non-airborne brake wear particles on the apical side (referred as pseudo-ALI approach as described by Endes et al. 2014). The concentrations of non-airborne brake wear particles (i.e., samples nLM and NAO) were 2,1 and $0.5 \mathrm{mg} /$ $\mathrm{mL}$, considering that majority of the particles sediments on the cells within $24 \mathrm{~h}$ and taking into account the effective growth area of the insert $\left(4.2 \mathrm{~cm}^{2}\right)$, the particle deposition corresponds to $\sim 48,24$ and $12 \mu \mathrm{g} / \mathrm{cm}^{2}$, respectively. Cells in 12-well inserts were exposed to $50 \mu \mathrm{L}$ of suspension of sfLM because of the limited particle mass received during the $16 \mathrm{~h}$ braking cycles, the concentration for all sfLM used was $33 \mu \mathrm{g} / \mathrm{mL}$, which correspond with deposition $3.7 \mu \mathrm{g} /$ $\mathrm{cm}^{2}$ (effective growth area of 12-well inserts is $0.9 \mathrm{~cm}^{2}$ ).

\section{Cell morphology}

After the $24 \mathrm{~h}$ incubation period, the co-cultures were fixed for $15 \mathrm{~min}$ in 3\% paraformaldehyde (PFA) in phosphate buffered saline (PBS), treated with $0.1 \mathrm{M}$ glycine in PBS for 15 min, and subsequently treated with $0.2 \%$ Triton X-100 in PBS for 15 min to permeabilise the cell membrane. Phalloidin rhodamine (R-415; Molecular Probes, Life Technologies, Switzerland) was used to stain the F-actin cytoskeleton (1:50 dilution), while 4',6-diamidin-2-fenylindol (DAPI, [100 mg/mL], Sigma-Aldrich, Switzerland) stained nucleus at a 1:50 dilution. Finally samples were embedded in Glycergel (DAKO Schweiz AG, Switzerland). An inverted laser scanning confocal microscope (LSM 710, Zeiss, Germany) was used for the sample visualisation. Image processing was performed using the restoration software IMARIS (Bitplane AG, Switzerland).

\section{Cell viability (propidium iodide assay)}

To investigate cell viability, cells were detached from the insert with trypsin-EDTA (0.05\%, Gibco, USA) using the method previously described by Clift et al. (2017). Exposed cells were incubated with propidium iodide (PI) (AnnexinV-FLUOS staining kit, Roche Diagnostics, Switzerland) to stain necrotic cells for $15 \mathrm{~min}$ at RT and then immediately analysed by flow cytometry [LSR Fortessa (3 laser, 4-blue2-red-2-violet (405 nm (violet); $488 \mathrm{~nm}$ (blue); $640 \mathrm{~nm}$ (red)) BD Biosciences, Basel, Switzerland)]. Untreated cells were incubated at $-80{ }^{\circ} \mathrm{C}$ for $1 \mathrm{~h}$ as a positive control to induce necrosis. The detailed gating strategy is explained in the SI.

\section{Biochemical analysis}

- Oxidative stress response

The concentration of total glutathione (GSH) was determined with a diagnostic glutathione assay kit (Cayman Chemical Company, USA), following the manufacturer's instructions. GSH values are reported relative to the total amount of protein of each sample determined by the Pierce bicinchoninic acid (BCA) protein assay kit (Pierce Protein research Products, Thermo Scientific, USA). Cells exposed to $135 \mathrm{mM}$ tert-butyl hydrogen peroxide (tBHP) served as the positive control.

- Cytokine/chemokine quantification

The (pro-)inflammatory response was measured by quantifying the amount of the (pro-)inflammatory mediators released into the lower medium chamber, e.g., tumor necrosis factor $\alpha$ (TNF- $\alpha$ ), interleukin-1 $\beta$ (IL-1 $\beta$ ) and interleukin-8 (IL-8) via enzyme-linked immunosorbent assay (ELISA) using the commercially available DuoSet ELISA Development Kit (R\&D Systems, Switzerland) according to the supplier's protocol. Co-cultures treated basolaterally with Lipopolysaccharide (LPS from Escherichia coli at $[1 \mu \mathrm{g} / \mathrm{mL}]$ ) for $24 \mathrm{~h}$ acted as the positive control. No particle interference was observed at any of the applied concentration, each ELISA kit was tested separately (data not shown).

\section{Statistical analysis}

All data is presented as the mean \pm standard error of the mean (STEM). A total of three independent experiments $(n=3)$ have been performed for all endpoints. Statistical analysis was performed using GraphPad Prism 6 (GraphPad 
Software Inc., USA). Assuming normal distribution of the data sets, a parametric one-way analysis of variance (ANOVA) followed by Dunnett's multiple comparison test was performed. Results were considered significant if $p<0.05$.

\section{Results}

\section{Sample characterisation}

SEM images of both non-airborne samples (nLM and NAO) and 1-2 $\mu \mathrm{m}$ size fraction of low-metallic sample are shown at Fig. 1a-d, respectively. SEM micrographs show the heterogeneity of the samples. Rod-like particles with smaller agglomerates attached on the surface were observed (Fig. 1a). EDS elemental analysis proved the iron origin of the rod in the nLM sample (Fig. 1a'). No visual difference between the two non-airborne samples (nLM and NAO) was observed. Agglomerates of smaller particles in the submicron size range on the surfaces of the bulk materials were visualised in both samples (Fig. 1b, c). The importance of particle separation by size was indicated (Fig. 1d); a homogenous sample has been observed in the 1-2 $\mu \mathrm{m}$ fraction of sfLM sample. All elements detected by EDS are summarized in Table 1; however, carbon, oxygen, sulphur, potassium, silicon and iron were detected in all samples. The presence of gold present in EDS spectra originates from spin-coating of the sample.

Raman microspectroscopy confirmed the presence of carbon (either amorphous carbon or graphite) in all samples. Furthermore, the presence of hematite $\left(\alpha-\mathrm{Fe}_{2} \mathrm{O}_{3}\right)$, graphite and amorphous carbon in the nLM sample (Fig. 2a), silicon carbide ( $\mathrm{SiC}$ ) (spectrum not shown), anatase $\left(\mathrm{TiO}_{2}\right)$, and hematite $\left(\alpha-\mathrm{Fe}_{2} \mathrm{O}_{3}\right)$ in NAO sample (Fig. 2b) and graphite in sfLM sample (Fig. 2c) was revealed.

The Raman spectra of the nLM (Fig. 2a) and NAO (Fig. 2b) samples show the presence of $\alpha-\mathrm{Fe}_{2} \mathrm{O}_{3}$ with significant bands at 225, 296 and $405 \mathrm{~cm}^{-1}$. Narrow band at $\sim 1580 \mathrm{~cm}^{-1}$ in $\mathrm{nLM}$ and sLM samples confirms the presence of graphite (Wang et al. 1990), while broad bands at $\sim 1355$, and $\sim 1530 \mathrm{~cm}^{-1}$ demonstrate the amorphous carbon content in all samples (Scheibe et al. 1995). Bands at $\sim 152, \sim 201$, and $\sim 391 \mathrm{~cm}^{-1}$ proof the presence of $\mathrm{TiO}_{2}$ in form of anatase (Choi et al. 2005) in NAO sample (Fig. 2b).

TEM micrographs (Fig. 2d-f) confirm the heterogeneity of the samples. Different particle shapes and sizes can be observed, such as needle-like particle structures at submicron sizes (Fig. 2d). Smaller particles can agglomerate and adhere to the surface of bulk materials (Fig. 2e). The presence of small particles ( $\mathrm{nm}$ size range) besides bigger ( $>200 \mathrm{~nm}$ diameter) carbon-based spheres can be also observed (Fig. 2f).
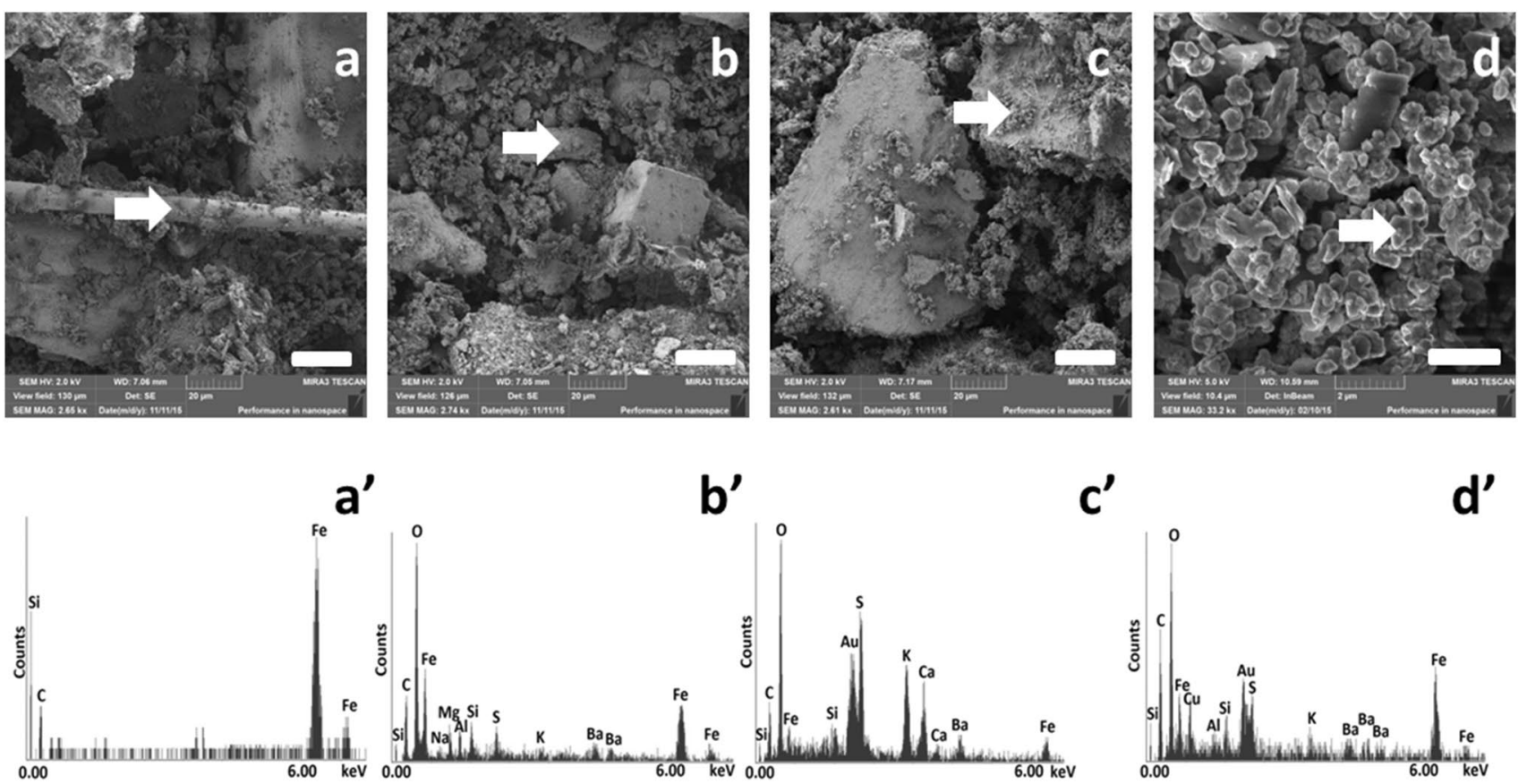

Fig. 1 SEM micrographs of nLM (a, b) with corresponding EDS spectra (a', b'), NAO sample (c) with corresponding EDS spectrum (c') and 1-2 $\mu \mathrm{m}$ size fraction of sfLM sample (d) with corresponding EDS spectrum (d'). White arrow refers to the spot of EDS scanning 
Table 1 Summary of all applied samples together with their biological response (black arrows with star ( $\uparrow^{*}$ ) show significant increase, simple arrows $(\uparrow)$ show tendency)

\begin{tabular}{|c|c|c|c|c|c|c|}
\hline \multicolumn{2}{|l|}{ Brake formulation } & \multicolumn{4}{|l|}{ Low-metallic } & \multirow{2}{*}{$\begin{array}{l}\text { Non-asbestos organic } \\
\text { Non-airborne }\end{array}$} \\
\hline \multicolumn{2}{|l|}{ Particle fraction } & Non-airborne & $2-4 \mu \mathrm{m}$ & $1-2 \mu \mathrm{m}$ & $0.25-1 \mu \mathrm{m}$ & \\
\hline \multicolumn{2}{|l|}{ Elemental analysis (EDS) } & $\begin{array}{l}\mathrm{Al}, \mathrm{Ba}, \mathrm{C}, \mathrm{Fe}, \mathrm{K}, \mathrm{Na}, \mathrm{O} \\
\mathrm{S}, \mathrm{Si}\end{array}$ & \multicolumn{3}{|c|}{$\mathrm{Al}, \mathrm{Ba}, \mathrm{C}, \mathrm{Ca}, \mathrm{Cu}, \mathrm{Fe}, \mathrm{K}, \mathrm{Mg}, \mathrm{O}, \mathrm{S}, \mathrm{Si}, \mathrm{Ti}$} & $\mathrm{Ba}, \mathrm{Ca}, \mathrm{C}, \mathrm{Fe}, \mathrm{K}, \mathrm{O}, \mathrm{S}, \mathrm{Si}$ \\
\hline \multicolumn{2}{|c|}{$\begin{array}{l}\text { Phase analysis (Raman microspectros- } \\
\text { copy) }\end{array}$} & $\begin{array}{l}\text { Amorphous carbon, } \\
\text { graphite, } \mathrm{Fe}_{2} \mathrm{O}_{3}, \mathrm{Fe}_{3} \mathrm{O}_{4}\end{array}$ & \multicolumn{3}{|c|}{ Amorphous carbon, graphite, $\mathrm{SiC}$} & $\begin{array}{l}\text { Amorphous carbon, } \\
\text { graphite, } \mathrm{TiO}_{2}, \mathrm{Fe}_{2} \mathrm{O}_{3}\end{array}$ \\
\hline \multicolumn{2}{|l|}{ Exposure scenario } & $\begin{array}{l}\text { Mild occupational } \\
\text { exposure }\end{array}$ & \multicolumn{3}{|c|}{ Ambient conditions } & $\begin{array}{l}\text { Mild occupational expo- } \\
\text { sure }\end{array}$ \\
\hline \multicolumn{2}{|l|}{ Cytotoxicity } & $\uparrow$ & $\uparrow$ & $\uparrow$ & $\uparrow$ & $\uparrow$ \\
\hline \multicolumn{2}{|l|}{ Oxidative stress } & - & - & - & - & - \\
\hline \multirow[t]{3}{*}{ (Pro-)inflammatory mediators } & IL-8 & - & - & - & - & $\uparrow *$ \\
\hline & IL-1 $\beta$ & $\uparrow$ & - & - & - & - \\
\hline & TNF- $\alpha$ & - & - & - & - & - \\
\hline
\end{tabular}

Elemental analysis was performed using energy-dispersed spectroscopy (EDS); cell viability was assessed by measuring propidium iodide (PI) positive cells; oxidative stress was investigated by measuring total glutathione (GSH) presented as relative to total protein; (pro-)inflammatory response was assessed by measuring tumor necrosis factor- $\alpha$ (TNF- $\alpha$ ) and interleukin- $1 \beta$ and -8 (IL- $1 \beta$ and IL-8)
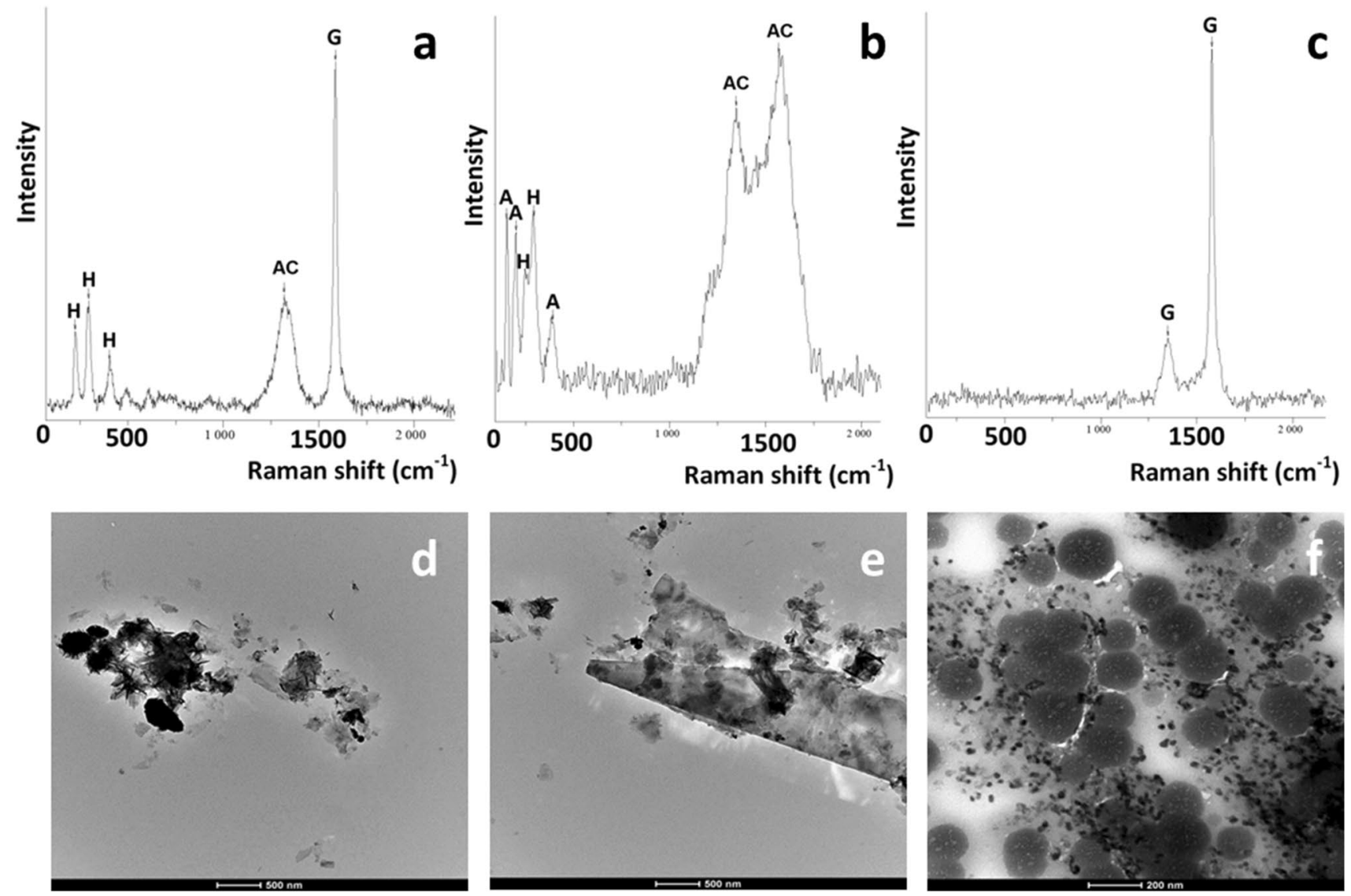

Fig. 2 Representative Raman spectra of nLM sample (a), NAO sample (b) and sfLM sample (c) with characteristic bands for hematite (H), amorphous carbon (AC), graphite (G), and anatase (A) and TEM micrographs of nLM (d, e) and 2-4 $\mu \mathrm{m}$ sfLM sample (f) 


\section{Particle exposure to cell surface}

The particles suspended in sRPMI were applied on the surface (pseudo-ALI approach) of the cells cultured at ALI at different concentrations of non-airborne brake wear particles (i.e., 2,1 and $0.5 \mathrm{mg} / \mathrm{mL}$ ), resulting in a very thin layer $(\sim 230 \mu \mathrm{m})$ of the suspension with particle deposition of around $\sim 48,24$ and $12 \mu \mathrm{g} / \mathrm{cm}^{2}$, respectively. The concentration for all sfLM $(33 \mu \mathrm{g} / \mathrm{mL})$ corresponds with a deposition of $\sim 3,7 \mu \mathrm{g} / \mathrm{cm}^{2}$. It was not possible to increase this concentration because of limited particle mass received during the sampling process.

\section{Cell viability and morphology}

Flow cytometry was used to detect the necrotic cell population. The fold increase of cells positively stained by PI compared to untreated cells is shown in Fig. 3a. No significant change in viability was observed across all samples analysed. However, an increase for PI positive cells for the NAO exposed samples was seen. Cell morphology was investigated by laser scanning microscopy (LSM) and no difference compared to untreated cells was observed in all 'low-metallic' samples (i.e., nLM and sfLM). However, morphology change was seen for the cytoskeleton of cells exposed to NAO (see Fig. 3b). The decrease in cell layer thickness could be a result of the decreased number of cells observed. Furthermore, most cells became disorganized, while losing cellular contacts and regular shape.

\section{Oxidative stress and (pro-)inflammatory response}

The total amount of glutathione (GSH) relative to total protein was analysed to evaluate oxidative stress (Fig. 4a). No significant changes $(p>0.05)$ to the oxidative stress status in all cell cultures were seen. A decrease in total glutathione levels was only observed for the positive control ( $t \mathrm{BHP})$.

The cytokine release of IL-8 (Fig. 4b), TNF- $\alpha$ (Supplementary Fig. 1b) and IL-1 $\beta$ (Supplementary Fig. 1c) was determined to evaluate the (pro-)inflammatory response of the co-culture model. A statistically significant increase $(p<0.05)$ was observed in regards to the release of IL-8 following NAO exposure at all concentrations and the positive control.

\section{Discussion}

The increase of brake wear particulate emissions released into the environment correlates with increasing traffic density. The aim of this study was to correlate the physicochemical characteristics of particles released from different brake pads with their possible adverse effects in vitro using a 3D human alveolar model. The brake pads for small passenger cars used for the generation of wear particles are currently commercially available on the US and European market.

Hereby we presented a combination of methods which are necessary to obtain overall information about such a heterogeneous material leading to possible prediction of adverse health effects. All the results obtained in this study are summarized in Table 1.

\section{Brake wear debris}

Particles settled on the bottom of the environmental chamber of the dynamometer are presented as 'non-airborne', while 'airborne' particles were sorted into different size fractions using an aerosol sampling system within the environmental chamber of the dynamometer. However, a previous study (Kukutschová et al. 2011) revealed micro-sized particles present in the form of clusters in the non-airborne fraction and nano-sized particles attached on the surface of larger micro-sized airborne particles in all size fractions as separated using an impactor. Brake pads with 'low-metallic' formulation (i.e., $\mathrm{nLM}$ and sfLM samples) typically consist of organic compounds (mainly phenolic resin) mixed with a small amount of metallic components (up to $3 \%$ by mass), providing high friction and good braking capacity at high temperatures. On the other hand, brake pads with 'nonasbestos' formulation (i.e., NAO sample) are relatively soft, contain thermally less stable components and, therefore, lose the braking capacity at high temperatures, and thus release more wear debris than other types of brake pads (Grigoratos and Martini 2015; Lemen 2004).

As previously shown, heat and high pressure generated by friction processes result in morphological and chemical composition differences of released wear particles compared to the original brake formulation (Blau and Meyer Iii 2003; Filip et al. 1997; Kukutschová et al. 2009; Österle et al. 2001). EDS results corresponding with Raman microspectroscopy results showed the presence of carbonaceous materials such as amorphous carbon and graphite in all samples. Amorphous carbon is likely produced by oxidative wear of phenolic resin, condensation and subsequent deposition from the volatiles, on the other hand graphitic structures in the form of fine or coarse particles are most probably deposited from abrasive wear (Kukutschová et al. 2011). Since the exact formulation of each brake pad is manufacturer's proprietary, the comparison of the original brake pad with obtained brake wear particles was not possible. However, iron or iron oxide powder, together with quartz, zirconium, and aluminium oxide are the most common abrasive constituents (Grigoratos and Martini 2015; Kazimirova et al. 2016). Silicon carbide detected in sfLM sample is used as an abrasive material for brake pads improving the mechanical 


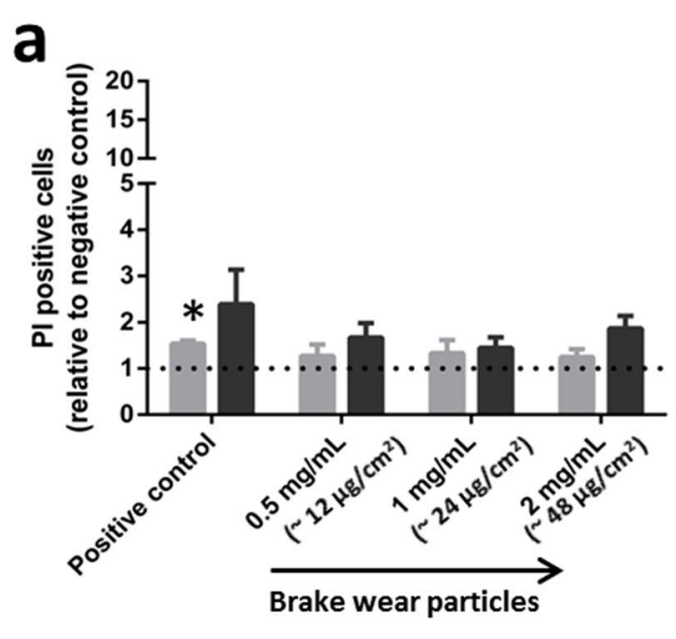

b

Untreated cells
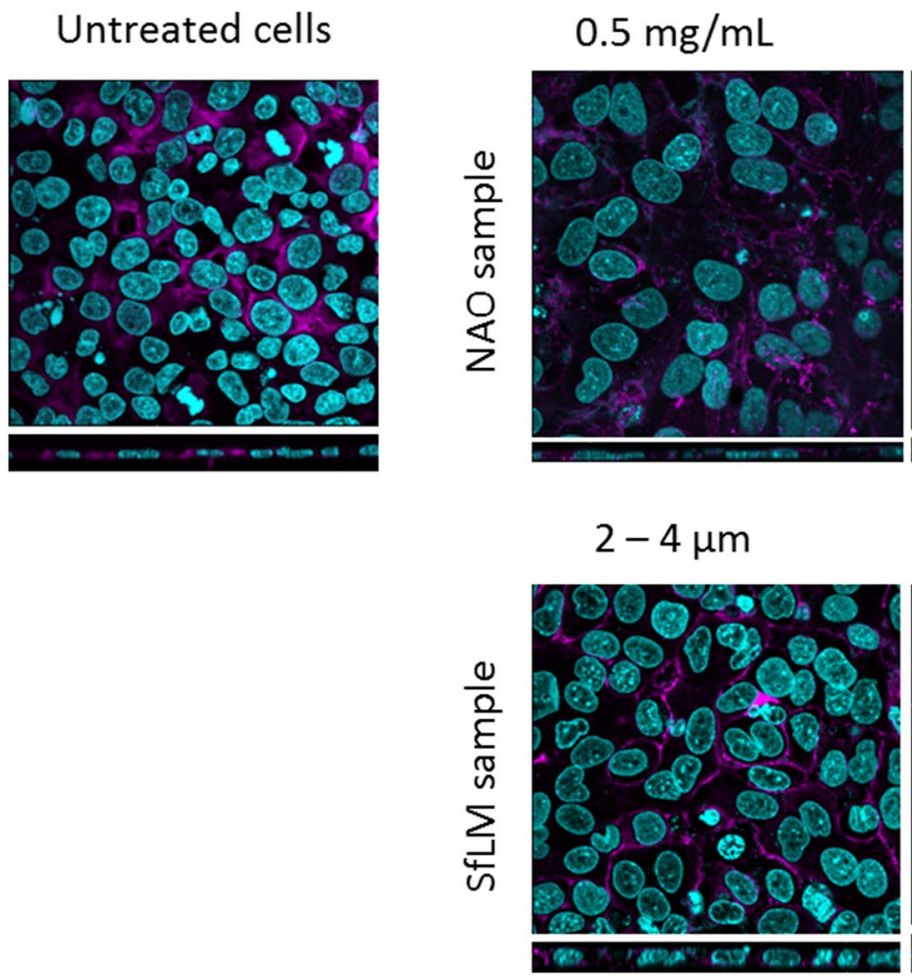
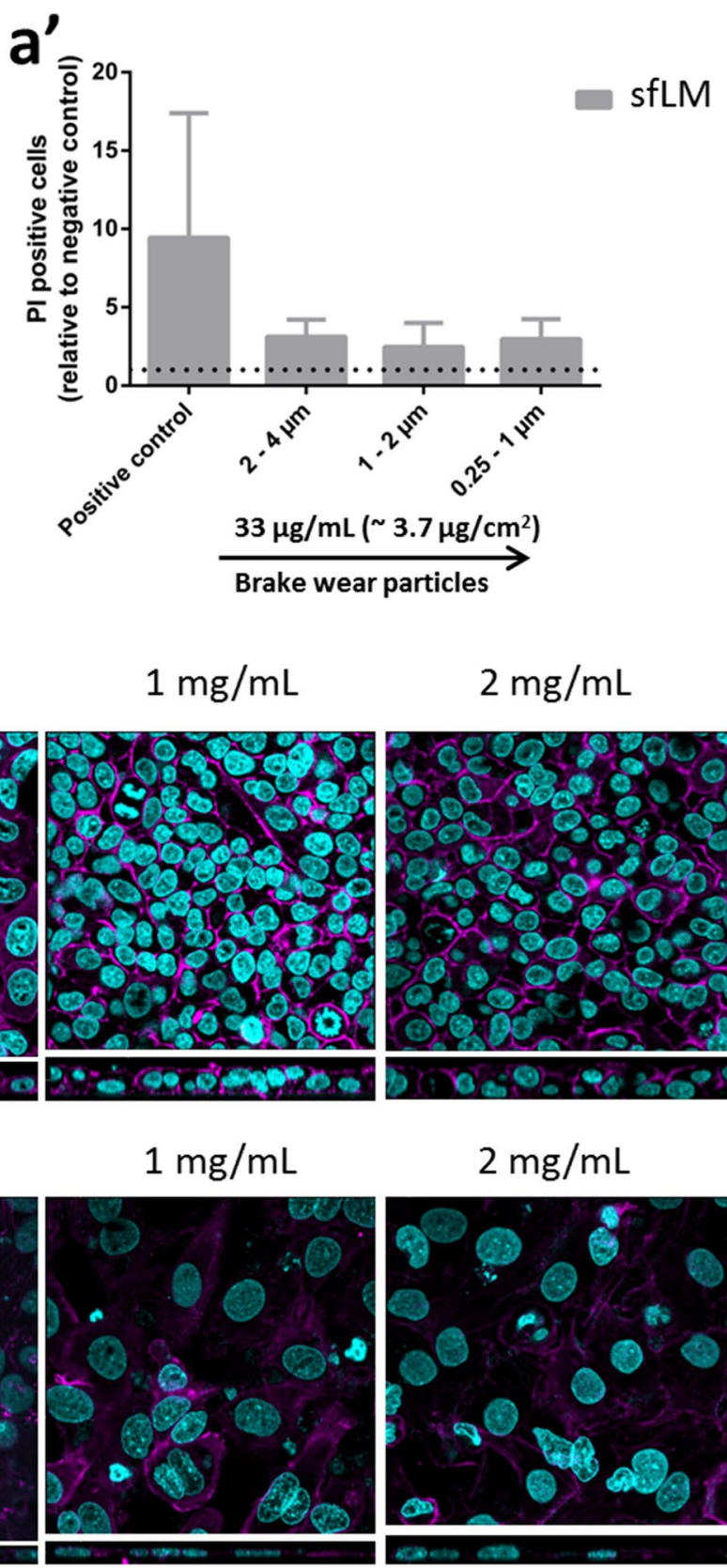

$1 \mathrm{mg} / \mathrm{mL}$

$2 \mathrm{mg} / \mathrm{mL}$
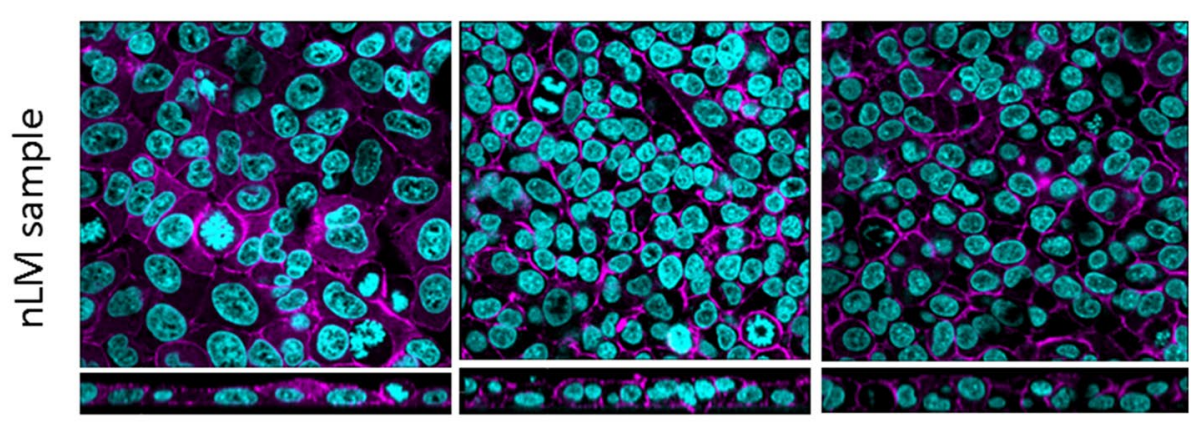

$2 \mathrm{mg} / \mathrm{mL}$

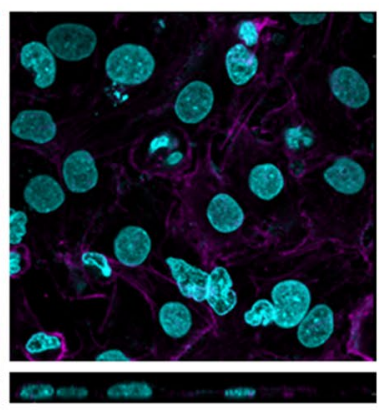

$1-2 \mu \mathrm{m}$

$0.25-1 \mu \mathrm{m}$

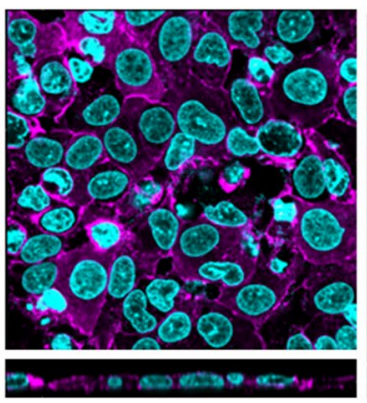


4Fig. 3 Cell viability (a) and cellular morphology (b) assessment in lung cell cultures exposed to brake wear particles. Cell viability (PI staining) was determined by comparison of brake wear particle exposed cell samples to the negative control (untreated cells) for nLM and NAO samples (a) and for sfLM samples (a') (results shown fold increase over untreated cells, dashed line $y=1$, i.e., indicating the level of negative control). Positive control: Untreated cells incubated at $-80^{\circ} \mathrm{C}$ for $1 \mathrm{~h}$ to induce necrosis. Data are presented as mean \pm standard error of the mean $(n=3)$. Data marked as $\left(^{*}\right)$ were considered statistically significantly increased compared to negative control $(p<0.05)$. Confocal laser scanning microscopy images of cocultures (b) exposed to nLM, NAO, and sfLM samples. Purple color shows the F-actin cytoskeleton, blue color shows nuclei. Scale bar is $20 \mu \mathrm{m}$

properties at high temperatures (Krenkel et al. 2002). In addition, the first composites applied in brake pad formulations were copper-coated silicon carbide composites (Kennedy et al. 1997), which could explain the presence of copper in EDS spectrum in the sfLM sample. Another material detected by Raman microspectroscopy was anatase $\left(\mathrm{TiO}_{2}\right)$ in NAO sample. The $\mathrm{TiO}_{2}$ probably originates from the original brake pad formula, which corresponds with earlier studies in terms of the trace elements observed in the brake wear dust (Garg et al. 2000; Hildemann et al. 1991; Sanders et al. 2003; Uexküll et al. 2005; Westerlund and Johansson 2002) as well as other elements like aluminium, barium, calcium, iron, magnesium, potassium, and sodium detected by EDS. It is important to mention that the detection limit of Raman microspectroscopy is in the range of the size of the laser spot, i.e., particles $<500 \mathrm{~nm}$ are most likely undetectable. Nevertheless, Raman microspectroscopy is a point analysis and has very good potential in the study of such heterogeneous samples. Additionally, EDS analysis showed a similar composition of all the tested samples with minor differences proving the deviations in the initial formulation of tested brake pads. Raman microspectroscopy also revealed the same basic composition of the brake wear debris, which is in good accordance with EDS analysis. Amorphous carbon was found in all studied samples by Raman microspectroscopy, which mostly originates from phenolic resin burnish and creates thin film of amorphous carbon which covered almost entire sample (Kukutschová et al. 2011; Peikertová et al. 2013).

SEM and TEM micrographs showed the heterogeneity of the samples, as well as the strong adherence of smaller agglomerates to the larger particles as already shown (Kukutschová et al. 2011). The adherence of the nano- and sub-micron particle agglomerates to larger particles can be also observed by TEM. Reason for this finding is hypothesized, that the smaller particles re-agglomerate to the larger particles during the drying process of TEM samples.

Particle size affects their deposition in the respiratory tract (Kumar et al. 2013; Pope et al. 2002; Samet et al. 2000). Inhaled fine and ultrafine particles may penetrate deep into the lungs causing oxidative stress and a (pro-)inflammatory effect; $\mathrm{PM}_{2.5}$ has been reported to penetrate into the small airways as well as the lung parenchyma, and can eventually translocate into the bloodstream (Geiser and Kreyling 2010; Oberdörster et al. 2005). Hagino et al. (2016) estimated that the realistic average mass concentration of ultrafine particles (mobility diameter $<100 \mathrm{~nm}$ ) in an urban environment is up to $10 \mu \mathrm{g} / \mathrm{m}^{3}$. An upper limit for workplace nanoparticle mass concentrations of $5 \mathrm{mg} / \mathrm{m}^{3}$ has been recommended by the Occupational Safety and Health Administration (OSHA, USA) standard for respirable nuisance dust (averaged over an $8 \mathrm{~h}$ work shift), which corresponds to daily alveolar mass dose of $0.13 \mathrm{mg} / \mathrm{cm}^{2}$ (clearance is neglected; $100 \%$ biopersistence is assumed). Hence, the maximum lifetime dose accumulated by a workers' occupational life is up to $420 \mathrm{mg} /$ $\mathrm{cm}^{2}$ (i.e., assumed to be 5 workdays per week for 50 weeks per year over 45 years; with $70 \%$ clearance).

Brake wear particles were roughly estimated to contribute to ambient $\mathrm{PM}_{10}$ concentrations up to $4 \mu \mathrm{g} / \mathrm{m}^{3}$ (Amato et al. 2009; Harrison et al. 2012; van der Gon et al. 2007; Wåhlin et al. 2006), so according to the assumption above, lifetime exposure of brake wear particles correspond to $\sim 2.4 \mu \mathrm{g} /$ $\mathrm{cm}^{2}$ under realistic ambient conditions, while in 'worst case scenario' can reach up to $\sim 180 \mu \mathrm{g} / \mathrm{cm}^{2}$. The concentration applied for NAO and nLM samples $\left(12-48 \mu \mathrm{g} / \mathrm{cm}^{2}\right)$ are too low to reach the upper limit of lifetime 'worst case scenario'; however, applied concentrations may simulate the mild risk of occupational exposures (lasting for 4-12 years). Lower doses applied for sfLM samples $\left(\sim 3.7 \mu \mathrm{g} / \mathrm{cm}^{2}\right)$ corresponding with realistic ambient conditions showed no significant changes in any biological responses investigated, suggesting that the concentrations used here might be too low to activate the biological response. It is worth noting that lifetime exposures most probably occur repeatedly at long-time period at low doses. In the present study, cells were exposed only once to particles, thus more so reflecting an acute exposure scenario. However, according to the authors' knowledge, only limited amount of the studies using the collected brake wear particles have been performed in a laboratory environment; therefore, it was difficult to estimate the most suitable concentration range for the present study (Kazimirova et al. 2016; Kukutschová et al. 2009; Malachova et al. 2016).

\section{Biological effects}

Lung cell culture models are widely used to investigate the cellular response and the mechanisms of the interaction of inhaled particles with the cells, and are considered as an effective alternative towards the primary screening of a large range of different particle sizes and types (Nichols et al. 2014; Rothen-Rutishauser et al. 2008a). The 3D model of the human alveolar epithelial tissue barrier applied in the present study combines two types of primary human immune cells 

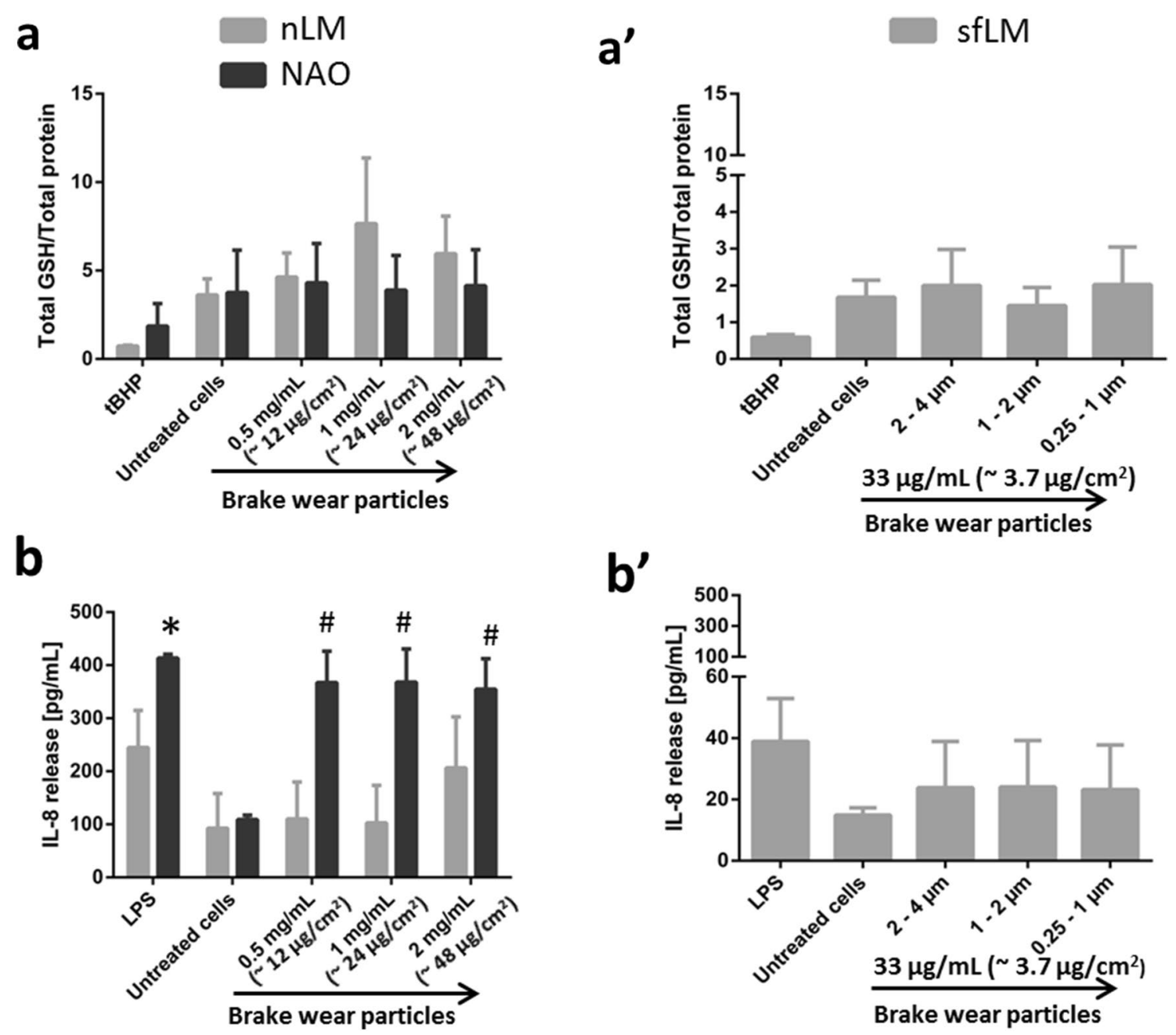

b'

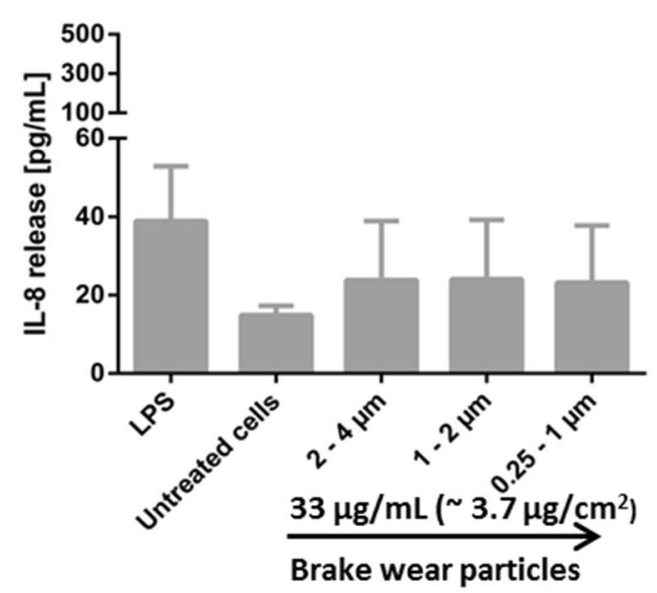

Fig. 4 Oxidative stress and (pro-)inflammatory response in lung cells exposed to brake wear particles. Oxidative stress levels in lung cell cultures following exposure to nLM and NAO samples (a) and to sfLM sample (a'). Quantification of IL-8 release for $\mathrm{nLM}$ and NAO samples (b) and for sfLM sample (b'). Data are presented as

with alveolar type II epithelial cells and offers the possibility to study the interaction of individual cell types with the tested particles as well as the interaction among cell types (Rothen-Rutishauser et al. 2008b). The co-culture model was transferred to the ALI $24 \mathrm{~h}$ prior to the exposure to allow the epithelial cells to produce and release surfactant-based proteins at the apical side of the cells (Blank et al. 2006). Although different types of ALI cell exposure systems are available on the market (Lenz and Karg 2009; Loret et al. 2016; Paur et al. 2011), nebulisation of hydrophobic material with such a broad range of particle sizes was not possible and thus based on previous experimental approaches (Endes et al. 2014), the pseudo-ALI approach was applied resulting in thin layer of media with particles covering the surface of the co-culture model. This approach does not remove the mean \pm standard error of the mean $(n=3)$. Data marked as $(*)$ were considered statistically significantly increased compared to negative control $(p<0.05)$. LPS lipopolysaccharide, tBHP tert-Butyl hydroperoxide

surfactant as the cell surface was not washed before particles were added.

Elements detected in brake wear particles like iron, copper, titanium, etc. may lead to oxidative stress and (pro-) inflammatory response (Riediker et al. 2004; Schaumann et al. 2004). Ghio and Cohen (2005) suggested that a possible pathway to induce (pro-)inflammatory or (pro-)fibrotic response can be through inhaled PM, which interferes in the lungs with iron homeostasis. Oxidative stress resulting from the disruption of iron homeostasis in the cells is associated with the initiation and coordination of the (pro-)inflammatory response. Induction of a (pro-)inflammatory response was also observed in a recent study with rats following exposure to magnetite (Tada et al. 2012). Iron-based particles were detected only quantitatively in all tested samples; however, it was not possible to correlate 
the (pro-)inflammatory response with the presence of iron in the samples. Furthermore, it has been shown that $\mathrm{TiO}_{2}$ particles can elevate the TNF- $\alpha$ and IL- $1 \beta$ release as well as cytotoxicity and the production of reactive oxygen species (Xiong et al. 2013; Yazdi et al. 2010). No significant increase in IL- $1 \beta$ or TNF- $\alpha$ production was observed; however, a significant increase in IL-8 release compared to negative control for NAO sample was detected which could be related to the presence of $\mathrm{TiO}_{2}$ (see Table 1). Furthermore, it was observed that a slight increase $(p>0.05)$ in cell death occurred after exposure to NAO compared to exposure to the $\mathrm{nL}$. Impaired cytoskeleton morphology following exposure to $2 \mathrm{mg} / \mathrm{mL}$ NAO sample was also seen. These findings, together with previous studies mentioned above (Xiong et al. 2013; Yazdi et al. 2010), lead the authors to hypothesize, that the presence of $\mathrm{TiO}_{2}$ in the brake formulations are directly related to the observed increased toxicity of brake wear particles.

\section{Conclusion}

The exposures of different brake wear particle samples and size fractions using concentrations corresponding to 'ambient conditions' (lifetime doses) and acute high dose exposure conditions were successfully achieved. Low doses of different size fractions as well as brake wear particles with low-metallic formulation applied for $24 \mathrm{~h}$ did not activate a biological response of the lung cell co-culture model used. Contrastingly, sample with non-asbestos formula initiated a heightened (pro-)inflammatory response, and reduced cell viability together with an altered cell morphology. This can be attributed to the presence of anatase in the sample.

In summary, we showed that brake pad formulation can significantly differ and the released particles can induce different adverse effects in in vitro lung models. Commercially available methods were applied to generate wear particles; however, these finding are not representative for all materials and all braking scenarios which may occur and further research upon defining representative procedure for generation, sampling, and quantification of brake wear particles is needed.

Acknowledgements The authors would like to thank the Sciex-NMS ${ }^{\text {ch }}$ program and the Adolphe Merkle Foundation for the financial support. The authors would like to thank Dr. Miroslav Vaculik (Nanotechnology Centre, VSB-TUO Ostrava) for provision and preparation of the brake wear samples.

\section{Compliance with ethical standards}

Conflict of interest The authors declare that they have no competing interests. The authors are entirely responsible for the written manuscript and the data presented herein.

Open Access This article is distributed under the terms of the Creative Commons Attribution 4.0 International License (http://creativeco mmons.org/licenses/by/4.0/), which permits unrestricted use, distribution, and reproduction in any medium, provided you give appropriate credit to the original author(s) and the source, provide a link to the Creative Commons license, and indicate if changes were made.

\section{References}

Amato F, Pandolfi M, Escrig A et al (2009) Quantifying road dust resuspension in urban environment by multilinear engine: a comparison with PMF2. Atmos Environ 43(17):2770. https://doi. org/10.1016/j.atmosenv.2009.02.039

Balakrishna S, Lomnicki S, McAvey KM, Cole RB, Dellinger B, Cormier SA (2009) Environmentally persistent free radicals amplify ultrafine particle mediated cellular oxidative stress and cytotoxicity. Part Fibre Toxicol 6(11):1. https://doi. org/10.1186/1743-8977-6-11

Blank F, Rothen-Rutishauser BM, Schurch S, Gehr P (2006) An optimized in vitro model of the respiratory tract wall to study particle cell interactions. J Aerosol Med 19:392. https://doi.org/10.1089/ jam.2006.19.392

Blank F, Rothen-Rutishauser B, Gehr P (2007) Dendritic cells and macrophages form a transepithelial network against foreign particulate antigens. Am J Resp Cell Mol 36(6):669. https://doi.org/10.1165/ rcmb.2006-0234OC

Blau PJ, Meyer Iii HM (2003) Characteristics of wear particles produced during friction tests of conventional and unconventional disc brake materials. Wear 255:7-12. https://doi.org/10.1016/ S0043-1648(03)00111-X

Choi HC, Jung YM, Kim SB (2005) Size effects in the Raman spectra of $\mathrm{TiO}_{2}$ nanoparticles. Vib Spectrosc 37(1):33. https://doi. org/10.1016/j.vibspec.2004.05.006

Clift MJD, Fytianos K, Vanhecke D, Hočevar S, Petri-Fink A, RothenRutishauser B (2017) A novel technique to determine the cell type specific response within an in vitro co-culture model via multi-colour flow cytometry. Sci Rep UK 7(1):434. https://doi. org/10.1038/s41598-017-00369-4

Endes C, Schmidt O, Kinnear C et al (2014) An in vitro testing strategy towards mimicking the inhalation of high aspect ratio nanoparticles. Part Fibre Toxicol 11(1):40. https://doi.org/10.1186/s1298 9-014-0040-x

Filip P, Kovarik L, Wright M (1997) Automotive brake lining characterization. In: Proceedings of the 15th annual SAE Brake Colloquium P-319 https://doi.org/10.4271/973024

Garg BD, Cadle SH, Mulawa PA, Groblicki PJ (2000) Brake wear particulate matter emissions. Environ Sci Technol 34(21):4463. https://doi.org/10.1021/es001108h

Gasser M, Riediker M, Mueller L et al (2009) Toxic effects of brake wear particles on epithelial lung cells in vitro. Part Fibre Toxicol 6(1):30. https://doi.org/10.1186/1743-8977-6-30

Geiser M, Kreyling WG (2010) Deposition and biokinetics of inhaled nanoparticles. Part Fibre Toxicol 7(1):2. https://doi. org/10.1186/1743-8977-7-2

Ghio AJ, Cohen MD (2005) Disruption of iron homeostasis as a mechanism of biologic effect by ambient air pollution particles. Inhal Toxicol 17(13):709. https://doi.org/10.1080/08958370500224482 
Grigoratos T, Martini G (2015) Brake wear particle emissions: a review. Environ Sci Pollut Res Int 22:2491. https://doi.org/10.1007/s1135 6-014-3696-8

Hagino H, Oyama M, Sasaki S (2016) Laboratory testing of airborne brake wear particle emissions using a dynamometer system under urban city driving cycles. Atmos Environ 131:269. https://doi. org/10.1016/j.atmosenv.2016.02.014

Harrison RM, Jones AM, Gietl J, Yin J, Green DC (2012) Estimation of the contributions of brake dust, tire wear, and resuspension to nonexhaust traffic particles derived from atmospheric measurements. Environ Sci Technol 46(12):6523. https://doi.org/10.1021/ es300894r

Hildemann LM, Markowski GR, Cass GR (1991) Chemical composition of emissions from urban sources of fine organic aerosol. Environ Sci Technol 25(4):744. https://doi.org/10.1021/es00016a021

Karlsson HL, Nilsson L, Moller L (2005) Subway particles are more genotoxic than street particles and induce oxidative stress in cultured human lung cells. Chem Res Toxicol 18:19. https://doi. org/10.1021/tx049723c

Kazimirova A, Peikertova P, Barancokova M et al. (2016) Automotive airborne brake wear debris nanoparticles and cytokinesisblock micronucleus assay in peripheral blood lymphocytes: a pilot study. Environ Res 148:443. https://doi.org/10.1016/j.envre s.2016.04.022

Kennedy FE, Balbahadur AC, Lashmore DS (1997) The friction and wear of $\mathrm{Cu}$-based silicon carbide particulate metaal matrix composites for brake applications. Wear 203:715. https://doi. org/10.1016/S0043-1648(96)07451-0

Krenkel W, Heidenreich B, Renz R (2002) C/C-SiC composites for advanced friction systems. Adv Eng Mater 4(7):427. https://doi.org/10.1002/1527-2648(20020717)4:7<427::AIDADEM427>3.0.CO;2-C

Kukutschová J, Roubíček V, Malachová K et al (2009) Wear mechanism in automotive brake materials, wear debris and its potential environmental impact. Wear 267:5-8. https://doi.org/10.1016/j. wear.2009.01.034

Kukutschová J, Moravec P, Tomášek V et al (2011) On airborne nano/ micro sized wear particles released from low-metallic automotive brakes. Environ Pollut 159:998. https://doi.org/10.1016/j.envpo 1.2010.11.036

Kumar P, Pirjola L, Ketzel M, Harrison RM (2013) Nanoparticle emissions from 11 non-vehicle exhaust sources-a review. Atmos Environ Health Perspect 67:252. https://doi.org/10.1016/j.atmos env.2012.11.011

Lawrence S, Sokhi R, Ravindra K, Mao H, Prain HD, Bull ID (2013) Source apportionment of traffic emissions of particulate matter using tunnel measurements. Atmos Environ 77:548. https://doi. org/10.1016/j.atmosenv.2013.03.040

Lehmann A, Brandenberger C, Blank F, Gehr P, Rothen-Rutishauser B (2010) A 3D model of the human epithelial airway barrier. In: Yarmush ML (ed) Alternatives to animal testing. Artech House, Norwood, Massachusetts, USA, pp 239-260

Lemen RA (2004) Asbestos in brakes: exposure and risk of disease. Am J Ind Med 45(3):229. https://doi.org/10.1002/ajim.10334

Lenz AG, Karg E, Lentner B et al (2009) A dose-controlled system for air-liquid interface cell exposure and application to zinc oxide nanoparticles. Part Fibre Toxicol 6:1743-8977. https://doi. org/10.1186/1743-8977-6-32

Loret T, Peyret E, Dubreuil M et al (2016) Air-liquid interface exposure to aerosols of poorly soluble nanomaterials induces different biological activation levels compared to exposure to suspensions. Part Fibre Toxicol 13(1):58. https://doi.org/10.1186/s1298 9-016-0171-3

Malachova K, Kukutschova J, Rybkova Z et al (2016) Toxicity and mutagenicity of low-metallic automotive brake pad materials.
Ecotoxicol Environ Saf 131:37. https://doi.org/10.1016/j.ecoen v.2016.05.003

Mathissen M, Scheer V, Vogt R, Benter T (2011) Investigation on the potential generation of ultrafine particles from the tire-road interface. Atmos Environ 45:6172. https://doi.org/10.1016/j.atmos env.2011.08.032

Nichols JE, Niles JA, Vega SP, Argueta LB, Eastaway A, Cortiella J (2014) Modeling the lung: design and development of tissue engineered macro- and micro-physiologic lung models for research use. Exp Biol Med (Maywood) 239:1135. https://doi. org/10.1177/1535370214536679

Oberdörster G, Oberdörster E, Oberdörster J (2005) Nanotoxicology: an emerging discipline evolving from studies of ultrafine particles. Environ Health Perspect 113:823. https://doi.org/10.1289/ ehp.7339

Österle W, Griepentrog M, Gross T, Urban I (2001) Chemical and microstructural changes induced by friction and wear of brakes. Wear 251(1-12):1469. https://doi.org/10.1016/S0043 -1648(01)00785-2

Paur HR, Cassee FR, Teeguarden J et al (2011) In-vitro cell exposure studies for the assessment of nanoparticle toxicity in the lung - a dialog between aerosol science and biology. J Aerosol Sci 42(10):668. https://doi.org/10.1016/j.jaerosci.2011.06.005

Peikertová P, Kukutschová J, Vávra I et al (2013) Water suspended nanosized particles released from nonairborne brake wear debris. Wear 306(1-2):89. https://doi.org/10.1016/j. wear.2013.07.008

Peters A, Wichmann HE, Tuch T, Heinrich J, Heyder J (1997) Respiratory effects are associated with the number of ultrafine particles. Am J Respir Crit Care Med 155:1376. https://doi.org/10.1164/ ajrccm.155.4.9105082

Pope CA, Burnett RT, Thun MJ et al (2002) Lung cancer, cardiopulmonary mortality, and long-term exposure to fine particulate air pollution. J Am Med Assoc 287:1132. https://doi.org/10.1001/ jama.287.9.1132

Riediker M, Devlin RB, Griggs TR et al (2004) Cardiovascular effects in patrol officers are associated with fine particulate matter from brake wear and engine emissions. Part Fibre Toxicol 1(2):2. https ://doi.org/10.1186/1743-8977-1-2

Rothen-Rutishauser BM, Kiama SG, Gehr P (2005) A three-dimensional cellular model of the human respiratory tract to study the interaction with particles. Am J Respir Cell Mol Biol 32:281. https ://doi.org/10.1165/rcmb.2004-0187OC

Rothen-Rutishauser B, Blank F, Mühlfeld CGP (2008a) In vitro models of the human epithelial airway barrier to study the toxic potential of particulate matter. Exp Opin Drug Metab Toxicol 4:1075. https ://doi.org/10.1517/17425255.4.8.1075

Rothen-Rutishauser B, Mueller L, Blank F, Brandenberger C, Muehlfeld C, Gehr P (2008b) A newly developed in vitro model of the human epithelial airway barrier to study the toxic potential of nanoparticles. Altex 25:191

Samet JM, Dominici F, Curriero FC, Coursac I, Zeger SL (2000) Fine particulate air pollution and mortality in 20 US cities, 1987-1994. N Engl J Med 343:1742. https://doi.org/10.1056/NEJM200012 143432401

Sanders PG, Xu N, Dalka TM, Maricq M (2003) Airborne brake wear debris: size distribution, composition, and comparison of dynamometer and vehicle tests. Environ Sci Technol 37:4060

Schaumann F, Borm PJA, Herbrich A et al (2004) Metal-rich ambient particles (particulate matter 2. 5) cause airway inflammation in healthy subjects. Am J Resp Crit Care 170(8):898. https://doi. org/10.1164/rccm.200403-423OC

Scheibe HJ, Drescher D, Alers P (1995) Raman characterization of amorphous carbon films. Fresen J Anal Chem 353(5):695. https ://doi.org/10.1007/BF00321352 
Schulz H, Harder V, Ibald-Mulli A et al (2005) Cardiovascular effects of fine and ultrafine particles. J Aerosol Med 18:1. https://doi. org/10.1089/jam.2005.18.1

Stone V, Miller MR, Clift MJD et al (2017) Nanomaterials versus ambient ultrafine particles: an opportunity to exchange toxicology knowledge. Environ Health Perspect 125(10):106002. https ://doi.org/10.1289/EHP424

Sun Q, Hong X, Wold LE (2010) Cardiovascular effects of ambient particulate air pollution exposure. Circulation 121(25):2755. https ://doi.org/10.1161/CIRCULATIONAHA.109.893461

Tada Y, Yano N, Takahashi H et al (2012) Acute phase pulmonary responses to a single intratracheal spray instillation of magnetite $\left(\mathrm{Fe}_{3} \mathrm{O}_{4}\right)$ nanoparticles in Fischer 344 Rats. J Toxicol Pathol 25(4):233. https://doi.org/10.1293/tox.25.233

Thorpe A, Harrison RM (2008) Sources and properties of non-exhaust particulate matter from road traffic: a review. Sci Total Environ 400:270. https://doi.org/10.1016/j.scitotenv.2008.06.007

Tjalve H, Henriksson J (1999) Uptake of metals in the brain via olfactory pathways. Neurotoxicology 20:181

Uexküll O, Skerfving S, Doyle R, Braungart M (2005) Antimony in brake pads-a carcinogenic component? J Clean Prod 13:19. https ://doi.org/10.1016/j.jclepro.2003.10.008

van der Gon HACD., Hulskotte JHJ, Visschedijk AJH, Schaap M (2007) A revised estimate of copper emissions from road transport in UNECE-Europe and its impact on predicted copper concentrations. Atmos Environ 41(38):8697. https://doi. org/10.1016/j.atmosenv.2007.07.033

Wåhlin P, Berkowicz R, Palmgren F (2006) Characterisation of traffic-generated particulate matter in Copenhagen. Atmos Environ 40(12):2151. https://doi.org/10.1016/j.atmosenv.2005.11.049

Wang Y, Alsmeyer DC, McCreery RL (1990) Raman spectroscopy of carbon materials: structural basis of observed spectra. Chem Mater 2:557. https://doi.org/10.1021/cm00011a018

Westerlund KG, Johansson C (2002) Emission of metals and particulate matter due to wear of brake linings in Stockholm. WIT Trans Ecol Environ 53:23. https://doi.org/10.2495/AIR020791

Wiedensohler A, Stratmann F, Tegen I (2000) Environmental particles particle-lung interactions. CRC Press, New York, pp 67-88

World Health Organisation WHO (2013) Health effects of particulate matter

Xiong S, George S, Yu H et al (2013) Size influences the cytotoxicity of poly (lactic-co-glycolic acid) (PLGA) and titanium dioxide $\left(\mathrm{TiO}_{2}\right)$ nanoparticles. Arch Toxicol 87(6):1075. https://doi.org/10.1007/ s00204-012-0938-8

Yazdi AS, Guarda G, Riteau N et al (2010) Nanoparticles activate the NLR pyrin domain containing 3 (Nlrp3) inflammasome and cause pulmonary inflammation through release of IL- $1 \alpha$ and IL- $1 \beta$. Proc Natl Acad Sci USA 107(45):19449. https://doi.org/10.1073/ pnas. 1008155107 